\title{
Daniel Stolzenberg
}

Egyptian Oedipus: Athanasius Kircher and the Secrets of Antiquity. University of Chicago Press, Chicago: 2015. Pp. xi +320. Hb, \$30.

This new treatment of the Jesuit polymath Athanasius Kircher (1601/2-1680), coming in the footsteps of recent contributions of Joscelyn Godwin (Athanasius Kircher's Theatre of the World: The Life and Work of the Last Man to Search for Universal Knowledge [Rochester, Vt: Inner Traditions, 2009]) and Paula Findlen (Athanasius Kircher: The Last Man Who Knew Everything [New York: Routledge, 2004]), is a sign of the current vitality of Kircherian scholarship. There is much that credits Daniel Stolzenberg's monograph, including its publication at a top academic press, its focus on Kircher's masterpiece Oedipus Aegyptiacus (1655), its dialogue with recent academic developments (such as Western esotericism), and Stolzenberg's own Kircherian bona fides.

Yet there are fundamental problems with this work, which at times make for a problematic read. The book is centered on the thesis that Oedipus Aegyptiacus was an antiquarian work. What does this mean? Stolzenberg defines antiquarianism as a curious and empirical study of the tangible remains of the past. This definition is linked with the author's acknowledged debt to the scholarly tradition that descends from Arnaldo Momigliano, according to whom early modern erudition ("an array of scholarly practices aimed at knowledge of the past" [21], which encompassed antiquarianism) spawned many of today's social sciences. This view tends to blur the boundaries between early modern scholarship and modern science in claiming that early modern erudition was a proto-scientific empiricism.

Yet one cannot help but wonder whether Momigliano's perspective was not colored by posterior judgment. For one, Kircher could not have intended to spawn modern historical scholarship: in fact, he believed that he had singlehandedly sorted out the riddle of the Egyptian hieroglyphs, to an extent that rendered any further scholarship redundant. Nor does Kircher come across as an empiricist: rather than beginning with the object, Kircher started from theory (the existence of a lineage of ancient wisdom or prisca theologia), which was then applied to the object. In this, he seems a scrupulous Aristotelian, rather than a modern empiricist. Kircher's attention to proof is simply a means of shoring up his theory: it holds only a demonstrative role, epitomized by the fact that, when evidence was insufficient, unpersuasive, or plainly contrary to theory, Kircher simply cast it away.

All this is acknowledged by Stolzenberg, at least partially. He maintains that, for Kircher, occult philosophy acted as a "historical framework to explain ancient objects and inscriptions" (29). He accepts that, for the German Jesuit, 
primary sources were only meaningful as a way of justifying his theories, as well as that Kircher mixed "state-of-the-art" scholarship with truly substandard uses of evidence.

Furthermore, Stolzenberg affirms that in the period, erudite research and the theory of prisca theologia were very much linked, and continued to be so well into the eighteenth century. Yet, is this not the same as acknowledging that erudite research was not necessarily as empiricist as Momiglianoinfluenced scholarship would have it? Stolzenberg seems to suggest this when he points to Anthony Grafton's argument that Isaac Casaubon's paradigmatic debunking of the antiquity of the Hermetic Corpus in 1614 was by no means theory-free. Stolzenberg's further observation that seventeenthcentury erudition was highly concerned with problems of iconography and symbolism also hints at this. Moreover, his description of post-eighteenthcentury historical scholarship as one favorable towards theories of progress raises the question of whether, in fact, classical historical research was empiricist at all.

Unfortunately, such conclusions erode Stolzenberg's definition of the terms "erudition" and "antiquarianism," his use of the word "empiricism" and the Momigliano-driven analogy he makes between experimental science and historical scholarship. Yet, if "antiquarianism" no longer means pure empirical study, what exactly does it mean? Can we simplify it to mean a detailed analysis of ancient artifacts?

Leaving this thorny problem of definition aside, one can still engage with the book by focusing on Stolzenberg's important argument that Kircher employed occult philosophy as a tool for explaining hieroglyphs. In this sense, Stolzenberg maintains that Kircher's book should be read not as an exposition of occult philosophy, but as an erudite use of this philosophy to solve a particular problem. The argument that occult ideas were the means, rather than the goal, of Kircher's work is persuasive, although not completely convincing.

First, Stolzenberg argues that, by comparison to occult philosophers like Marsilio Ficino, Cornelius Agrippa, or Francesco Patrizi, Kircher projected the persona of an "expert interpreter of the material remains of ancient civilizations" (55). The examples Stolzenberg adduces, such as Kaspar Schott's anecdotes, the scholarly perception of Kircher, and the Jesuit's own self-promotion, support this conclusion. Nevertheless, it has to be kept in mind that there is a difference between one's social projection, on the one hand, and one's substance, on the other.

Furthermore, Stolzenberg's argument that Kircher was different from occult philosophers such as Ficino and Agrippa in focusing primarily on 'history', rather than 'truth', is unassailable, but problematic. Comparing Kircher with 
Ficino and Agrippa comes across as anachronistic, since Kircher lived in a very different period. Moreover, the fact that Kircher was more minutely concerned with transmission and history than Ficino and Agrippa does not mean that his "universal history" did not have a philosophical core or aim. Finally, Stolzenberg's argument that Kircher's work was not a "vehicle to promote Hermetic philosophy" (29) can be countered by Kircher's own statement that his main goal is the "restoration of the hieroglyphic doctrine" (16), a version of prisca theologia. Stolzenberg's attempt at presenting this as a "different kind of restoration, an antiquarian reconstruction" (178) seems to mildly force the evidence.

In any case, the book's tendency to segregate "erudition" from "philosophy" comes across as arbitrary. The dichotomy stems from a polemical attempt at extricating Kircher from the old-fashioned view that saw him as advancing a pure (albeit disguised) form of Hermetic philosophy. Although Stolzenberg's rejection of this line of scholarship seems correct, his argument is overstated. In fact, Kircher's work can easily be perceived as a form of applied philosophy, much closer to contemporaneous alchemical and Paracelsian endeavors than to modern scholarship. Like Kircher, many alchemical philosophers used theory as a platform of practice. Yet the substance and truth of theory remained essential, just as Kircher's concept of prisca theologia was pivotal to his approach to hieroglyphics. Focus on practice does not diminish in any way the importance of the theoretical framework, which may fade in and out of view while always at work. It is regrettable that the author makes no attempt at engaging early modern alchemical philosophy, instead completely eliminating it from discussion by (artificially) separating it from occult philosophy. In the process, the book itself is deprived of a fundamental insight on how applied philosophy worked.

Moreover, the dissociation between "erudition" and "philosophy" also limits the book's insight into the substance of Kircher's interpretation of hieroglyphs. Much of the Stolzenberg's attention is taken up by the "mechanics" of Kircher's work, leading to little focus on its content. Only two pages of chapter four and roughly half of chapter seven actually addresse hieroglyphic interpretation. Such scarcity could be excused, had the author provided a truly insightful and objective explanation. There is certainly merit to his analysis of Kircher's "combinatory method" and the "impressae" approach. Yet this is overshadowed by too many apologetic asides - and even derogatory remarks. For instance, the author states that "mad though it may seem" (203) Kircher's interpretation had a certain method behind it, later adding that his reading "consisted of dense paragraphs of scholastic Latin mumbo jumbo" (208). His efforts are summed up as "nugatory." Such remarks can only reinforce the bias that has surrounded 
Kircher's work since the eighteenth century. There is little doubt that there is a substance to Kircher, and that many were compelled or repelled by it. Alas, the author is less interested in the "philosophical" perspective from which this substance can perhaps be best understood. True, we are mercifully directed to the "many studies of Kircher's theory of hieroglyphic symbolism" (199) but such suggestions do not redeem this particular book. In the end, the reader is left admiring the virtuosity of Stolzenberg's technical analysis, but regretting the lack of enlightenment about Kircher's hieroglyphic explanation.

Beyond such shortcomings, several parts of the book do offer an informative read. Such, for example, is chapter two's exploration of the fascinating dynamic between Kircher and Peiresc, offered with an impressive amount of detail. Likewise, chapter three places Kircher squarely within the little-known environment of Counter-Reformation Rome. Finally, the chapter on Jesuit censorship points out that this did not play the exclusively negative role we are accustomed to attribute to it, but often had a critical role akin to our contemporary "peer-review" system.

Georgiana D. Hedesan

University of Oxford

georgianahedesan@yahoo.com

DOI 10.1163/22141332-00202007-20 